knowledge through an international network to overcome shortage of information from own region (WHO Traditional Medicine Strategy, 2002-2005, 2002). We believe that multiple reference sources, especially those published from countries where herbal medicine is more commonly used, should be used in order to provide an evidence-based advice.

\title{
REFERENCES
}

Barnes J (2003) Pharmacovigilance of herbal medicines. Drug Safe 26(12): $829-851$

Ernst E, Cassileth BR (1998) The prevalence of complementary/alternative medicine in cancer: a systematic review. Cancer 83: 777-782

Liang HLM, Xue CCL, Zhou DH, Li CG (2003) Chinese herbal medicine for lung cancer: a critical literature review. Chin J Integ Tradit West Med 9: $157-160$

Liu CL, Wang YD, Jin XJ, Liu LP, Yu QW, Cai YC (2001) Clinical study of non-small cell lung cancer by Chinese herbal medicine combined with bronchial arterial chemotherapy. Chin J Integ Tradit West Med 7: $242-246$

Liu ZY, Wang ZG, Zhang W, Tian HM, Li H, Na DY, Cao DY, Liu Y, Li M (2002) Antitumor effect of BRM. Chin J Cancer Res 14 $195-201$

Menendez JA, Ropero S, del Barbacid MM, Montero S, Solanas M, Escrich E, Cortes-Funes H, Colomer R (2002) Synergistic interaction between vinorelbine and gamma-linolenic acid in breast cancer cells. Breast Cancer Res Treat 72: 203-219

Newell S, Sanson-Fisher RW (2000) Australian oncologists' self-reported knowledge and attitudes about non-traditional therapies used by cancer patients. Med J Aust 172: $110-113$

Qu X, Zheng GJ, Yang MX, Zhou W, Zhao L (2003) Experimental studies of antitumor proliferation and metastasis of a new Chinese herb AT-1. Chin J Cancer Res 15: 223-226

Stockley IH (ed) (2002) Stockley's Drug Interactions, , 6th edn. London: The Pharmaceutical Press

Werneke U, Earl J, Seydel C, Horn O, Crichton P, Fannon D (2004) Potential health risks of complementary alternative medicines in cancer patients. Br J Cancer 90: $408-413$

WHO Traditional Medicine Strategy 2002 - 2005 (2002). Available at http:// www.who.int/medicines/organization/trm/orgtrmmain.shtml (accessed December 14, 2003)

\section{Reply: Assessing health risks of complementary alternative medicines in cancer patients}

\author{
U Werneke*,', J Earl', C Seydel', O Horn', P Crichton' and D Fannon' \\ 'Department of Psychiatry, Homerton Hospital, East Wing, Homerton Row, London E9 6SR, UK
}

British Journal of Cancer (2004) 91, 996-997. doi: I 0. I038/sj.bjc.6602046 www.bjcancer.com

Published online 13 July 2004

(c) 2004 Cancer Research UK

Sir,

Drug information services such as the Chinese Medicine Advisory Service at the Medical Toxicology Unit at Guy's and St Thomas' Hospital Trust make an important contribution to the safety management of patients taking complementary alternative medicines (CAMs). We are aware that these services exist and increased resort to the service they offer is needed. Our proposal is that doctors will need to devote time to discussing CAM use in outpatient clinics although the complexities of side effects and interactions may require clinics which are run jointly with a local medicines information and toxicology services (Werneke et al, 2004). Such work may not be feasible in routine outpatient clinics where patients may be seen only briefly. Joint clinics would not only address drug safety concerns but also the patients' motivation for opting for CAMs, for instance to gain a greater degree of control over their illness and its treatment, and thereby to regain control over their lives (Sparber et al, 2000).

*Correspondence: $\mathrm{Dr} \cup$ Werneke;

E-mail: Ursula.Werneke@elcmht.nhs.uk

Published online 13 July 2004
We agree with Shia et al that herbal remedies may have beneficial synergistic effects with conventional therapies. However, patients may take CAMs for a variety of reasons including reduction of cytotoxicity and its associated side effects rather than increasing it. This is highlighted by an email we received in response to out study from a naturopath who asserted:' . . you will find that more people die of the chemotherapy than the cancer itself. Therefore if the herbs are making the chemo less effective this could be a beneficial thing...' Thus, there is a need to work out and implement an individualised treatment plan for each patient wishing to use CAMs, and this may be beyond the scope of a drug information service.

Shia et al suggest prospective studies to evaluate the interactions between conventional and complementary medicines. However, such studies may be difficult to conduct if there are reasons to suspect potentially serious interactions or a significant reduction in efficacy of the conventional treatment, which could lead to a reduction in survival time. It may not be ethically acceptable to opt for 'watchful waiting' in such cases, and one may wish to err on the side of caution. In view of this, we 
recommended stopping CAMs in some cases while monitoring for adverse effects in others. Prospective studies could be further complicated by the fact that many patients take combinations of remedies rather than one substance only, which may not always make it possible to attribute an adverse reaction unambiguously to one agent.

\section{REFERENCES}

Sparber A, Bauer L, Curt G, Eisenberg D, Levin T, Parks S, Steinberg SM, Wootton J (2000) Use of complementary medicine by adult patients participating in cancer clinical trials. Onc Nurs Forum 27: 623-630
In consequence, we feel that the research on and management of CAMs should be integrated into the conventional cancer care to provide a truly holistic approach and to enable clinicians to adapt CAMs and conventional therapies to patients' individual requirements and to take account of changes in the clinical course whenever they occur.

Werneke U, Earl J, Seydel C, Horn O, Crichton P, Fannon D (2004) Potential health risks of complementary alternative medicines in cancer patients. Br J Cancer 90: 408-413 